\title{
Molecular detection of Staphylococcus aureus enterotoxin genes isolated from mastitic milk and humans in El-Behira, Egypt
}

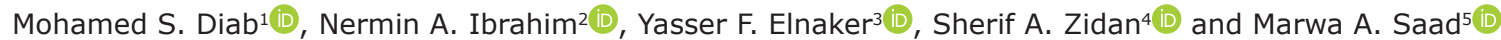

1. Department of Animal Hygiene and Zoonoses, Faculty of Veterinary Medicine, New Valley University, Egypt; 2. Department of Bacteriology, Faculty of Veterinary Medicine, Mansoura University, Egypt; 3. Department of Animal Medicine (Infectious Diseases), Faculty of Veterinary Medicine, New Valley University, Egypt; 4. Department of Animal Hygiene and Zoonoses, Faculty of Veterinary Medicine, University of Sadat City, Egypt; 5. Department of Food Control, Faculty of Veterinary Medicine, ShebinAl-Kom, Menofia University, Menofia, Egypt.

Corresponding author: Mohamed S. Diab, e-mail: mohameddiab333@gmail.com

Co-authors: NAI: nerminmousa64@gmail.com, YFE: yasserelnaker@yahoo.com, SAZ: shrifzidan@yahoo.com, MAS: Drmarwa2200@gmail.com

Received: 29-10-2020, Accepted: 01-02-2021, Published online: 16-03-2021

doi: www.doi.org/10.14202/IJOH.2021.70-77 How to cite this article: Diab MS, Ibrahim NA, Elnaker YF, Zidan SA, Saad MA (2021) Molecular detection of Staphylococcus aureus enterotoxin genes isolated from mastitic milk and humans in El-Behira, Egypt, Int. J. One Health, 7(1): 70-77.

\begin{abstract}
Background and Aim: Milk is a chief source of many nutrients. However, we must also bear in mind that it is a potential source for many cases of food poisoning. This study was conducted to investigate the prevalence of cow mastitis and evaluate the presence of enterotoxins and antibiotic resistance patterns in Staphylococcus aureus isolated from milk and contact humans in El-Behira Province, Egypt.
\end{abstract}

Materials and Methods: A total of 680 milk samples from 170 cows and 86 human samples consisting of 43 hand swabs and 43 nasal swabs were analyzed. The milk samples were subjected to the California mastitis test.

Results: The general occurrence was 23.1\% (157/680) where 48 quarters had clinical mastitis and 109 had subclinical mastitis. Subsequently, S. aureus was isolated in Baird-Parker agar where typical and atypical colonies were selected and submitted to coagulase and complementary tests. Out of 48 samples of mastitic milk studied, 16 (33.3\%) showed contamination by $S$. aureus whereas 109 samples of subclinical mastitis showed contamination in only 18 (16.5\%). On the opposite hand, of the 86 human samples, 33 revealed $S$. aureus contamination, corresponding to $38.37 \%$ of the samples. Furthermore, multiplex polymerase chain reaction targeting nuc and the staphylococcal enterotoxin-encoding genes sea, $s e b$, sec, sed, and see were performed after culture, revealing that $88.2 \%(30 / 34)$ of milk samples and $93.9 \%(31 / 33)$ of human samples were variably positive to those genes.

Conclusion: The use of nuc gene based PCR is an accurate and rapid method for $S$ aureus isolates detection. A high prevalence of multiple drug-resistant isolates of $S$. aureus recovered from both human and milk represents further evidence for possible veterinary hazards as well as public hazards, especially to those that consume milk from this region.

Keywords: antibiotic sensitivity, dairy production, enterotoxins, multidrug resistance, multiplex polymerase chain reaction, nuc gene, Staphylococcus aureus enterotoxin genes, Staphylococcus aureus.

\section{Introduction}

Mastitis has a significant impact on dairy production, affecting animal health, welfare and milk quality, and causing major economic losses to the dairy industry [1]. Staphylococcus aureus is one of the major bacterial pathogens causing bovine mastitis [2,3]. Subclinical and clinical mammary gland infection can produce large numbers of $S$. aureus, which are believed to be extremely contagious, and are easily spread through milking [4,5].

$S$. aureus is incriminated in most food toxicity outbreaks. Its pathogenicity is due to the production of staphylococcal enterotoxins (SEs) [6]. Several

Copyright: Diab, et al. This article is an open access article distributed under the terms of the Creative Commons Attribution 4.0 International License (http://creativecommons.org/licenses/ by/4.0/), which permits unrestricted use, distribution, and reproduction in any medium, provided you give appropriate credit to the original author(s) and the source, provide a link to the Creative Commons license, and indicate if changes were made. The Creative Commons Public Domain Dedication waiver (http:// creativecommons.org/ publicdomain/zero/1.0/) applies to the data made available in this article, unless otherwise stated. varieties of SES can be distinguished serologically. Most staphylococcal food intoxication outbreaks are associated with classical $S E$, sea-see; however, sea is the most widely implicated $[7,8]$. Several molecular techniques are used for the rapid, accurate detection of $S$. aureus isolates, including multiplex polymerase chain reaction (PCR) $[9,10]$.

$S$. aureus exist in the throats, nasal passages, hair, and skin of nearly $50 \%$ of healthy individuals. Food handlers are, therefore, assumed to be a potential source of contamination for food, either directly or indirectly $[11,12]$. Food handlers act as vehicles for human infection and may, therefore, pose a public health threat $[13,14]$. The signs of staphylococcal food poisoning, such as abdominal cramps, nausea, vomiting, and diarrhea, occur 2-4 $\mathrm{h}$ following the ingestion of contaminated foods, and vary in severity depending on health status of the individual and the amount of SEs ingested $[15,16]$.

The use of nuc gene-based PCR which encode thermonuclease is a very common use and can identify 
all isolates of $S$ aureus from intramammary infection faster than conventional culturing methods. There is a clear need for strict hygienic measures, to reduce the risk of bacterial contamination [17-19].

The use of antimicrobial drugs in humans and animals is poorly controlled, leading to the development of drug resistance. Multidrug-resistant bacteria, including $S$. aureus, are, therefore, frequently isolated from both humans and animals [20,21].

This study was conducted to investigate the prevalence of mastitis and evaluate the presence of enterotoxins and antibiotic resistance patterns in S. aureus isolated from milk and contact humans in El-Behira Province, Egypt.

\section{Materials and Methods}

\section{Ethical approval and informed consent}

All procedures performed in this study, including collection of human and milk samples from animals were done in accordance with the Egyptian ethical standards of the National Research Committee. All human subjects gave their consent for the collection of samples, with the agreement that any identifying details of the individuals should not be published.

\section{Study area and period}

This study was conducted in five dairy farms in El-Behera Governorate, which is a Governorates of Egypt with the capital city of Damanhur, located in the West Delta. The study was conducted from January to July 2020.

\section{Samples and sample preparation}

Samples were collected at random from El-Behira Province. The samples were 680 milk samples from 170 cows, and 86 human samples, including 43 hand swabs and 43 nasal swabs, from apparently healthy individuals in contact with the cows. The samples were transferred immediately to the laboratory under full aseptic conditions and tested for mastitis using the California mastitis test (CMT) followed by bacteriological isolation and identification of $S$. aureus. The histories of the animals and the results of clinical examination for the presence of clinical or subclinical mastitis were recorded.

\section{CMT}

The CMT is a screening test for mastitis [22]. The CMT results can be 0 (negative, trace); 1 (weak positive); 2 (distinct positive); or 3 (strong positive). A test score of 0 was interpreted as a negative result, while scores of 1 or 2 were considered subclinical mastitis, and a score of 3 indicated clinical mastitis. Herds with $25 \%$ or more cows with a CMT score of $>1$ were defined as positive for mastitis. The 680 milk samples collected from 170 cows were tested using being the CMT and aseptically gathered into sterile plastic tubes $(10-15 \mathrm{~mL} / \mathrm{sample})$. The positive samples were transported in an icebox to the laboratory.

\section{Pre-enrichment}

All samples were diluted with buffered peptone water at a proportion of 1:9.

\section{Isolation and identification of S. aureus}

All samples were cultured on mannitol salt agar (HiMedia, India) and then incubated at $37^{\circ} \mathrm{C}$ for $24 \mathrm{~h}$. Colonies suspected to be positive were recultured on Baird-Parker medium (HiMedia) with egg yolk tellurite emulsion (HiMedia) and incubated for 24-48 $\mathrm{h}$ at $37^{\circ} \mathrm{C}$. For further identification of their cultural, morphological, staining, and other biochemical characteristics, one colony was selected and streaked on mannitol salt agar and incubated at $37^{\circ} \mathrm{C}$ for $24-48 \mathrm{~h} \mathrm{[23].}$

\section{Morphological characteristics}

The smear contained Gram-positive, spherical cells arranged in irregular clusters after staining with Gram stain.

\section{Tube coagulase test}

Five typical colonies were incubated in a tube holding brain heart infusion broth (HiMedia) at a temperature of $37^{\circ} \mathrm{C}$ for $24 \mathrm{~h}$. Then, $0.3 \mathrm{~mL}$ was transported to a sterile tube containing $0.5 \mathrm{~mL}$ of rabbit plasma (HiMedia) and incubated at a temperature of $37^{\circ} \mathrm{C}$ for $6 \mathrm{~h}$. The reaction was scored as positive if the resulting clot was immobile when the tube was tilted.

\section{Catalase test}

The presence of catalase was tested using 3\% hydrogen peroxide $\left(\mathrm{H}_{2} \mathrm{O}_{2}\right)$. Liberation of oxygen bubbles was taken as indicating a positive reaction.

PCR of the nuc gene was used to confirm the classification of the cells as $S$. aureus. Entire isolates were then preserved in brain heart infusion broth with $15.0 \%$ glycerol at $-80^{\circ} \mathrm{C}$.

\section{DNA extraction and purification}

The chromosomal DNA of $S$. aureus was extracted by the boiling method as previously described Aldous et al. [24], with some alterations. Baird-Parker agar colonies were subcultured onto nutrient agar plates and incubated overnight $37^{\circ} \mathrm{C}$. Pure colonies were then transferred to $5 \mathrm{~mL}$ of nutrient broth and incubated with aeration at $37^{\circ} \mathrm{C}$, employing a shaker machine set at $120 \mathrm{rpm}$. One milliliter of each culture was then transferred into a $1.5 \mathrm{~mL}$ Eppendorf tube, centrifuged at 13,000 rpm for $10 \mathrm{~min}$, and the cell pellets were collected. The cell pellets were cleaned with distilled water and recentrifuged. Then, $200 \mu \mathrm{L}$ of deionized water was dissolved and mixed by manual shaking. Each Eppendorf tube was maintained at $100^{\circ} \mathrm{C}$ for $10 \mathrm{~min}$ followed by cold shock for $10 \mathrm{~min}$ on ice. The tubes were centrifuged again at 10,000 $\mathrm{rpm}$ for $10 \mathrm{~min}$, and the supernatant $(100-150 \mu \mathrm{L})$ was transferred into a fresh Eppendorf tube. The DNA purity and concentration were assessed using optical density with a NanoDrop ND-2000 spectrophotometer (NanoDrop Technologies, Rockland, DE, USA) 
at various wavelengths [25] and stored at $-80^{\circ} \mathrm{C}$ until further use.

\section{Multiplex PCR conditions}

PCR was used to detect the $n u c$ gene and the SEs sea, seb, sec, sed, and see the specific primers described in Table-1. The PCR mixture contained $1.5 \mathrm{mM} \mathrm{MgCl}$, $10 \mathrm{mM}$ Tris- $\mathrm{HCl}$ (pH 9.0), $50 \mathrm{mM}$ $\mathrm{KCl}, 0.1 \%$ Triton ${ }^{\circledR} \mathrm{X}-100,200 \mathrm{mM}$ of each deoxynucleotide triphosphate, $0.2 \mathrm{mM}$ of the individual primers, and $0.625 \mathrm{U}$ Taq polymerase (all the reagents from Promega Corp., Madison, Wisconsin, USA). The amplification was accomplished using an automatic thermocycler T-1 (Biometra). The positive control was $S$. aureus reference strain (ATCC 29213; sea, seb, sec, sed, and see).

The PCR cycles consisted of pre-heating at $95^{\circ} \mathrm{C}$ for $10 \mathrm{~m}$, denaturation at $94^{\circ} \mathrm{C}$ for $5 \mathrm{~m}$, annealing at $55^{\circ} \mathrm{C}$ for $30 \mathrm{~s}$, and extension at $72^{\circ} \mathrm{C}$ for $1.5 \mathrm{~min}$. The amplification was performed for 35 cycles with a final extension step at $72^{\circ} \mathrm{C}$ for $3.5 \mathrm{~min}$.

The PCR products were analyzed using electrophoresis in $1.5 \%$ agarose gel containing $0.5 \mathrm{mg}$ of ethidium bromide per $\mathrm{mL}$. Gels were visualized and photographed with Image Master VDS (Pharmacia Biotech). The sizes of the amplification products were estimated by comparison with a 100 bp DNA step ladder (Promega Corp.).

The antibiogram pattern of the isolated $S$. aureus to some antimicrobial agents was constructed using the disk diffusion method, as described by Clinical and Laboratory Standards Institute [26].

\section{Results and Discussion}

$S$. aureus is a widespread member of the natural microflora of the human nasal passages and skin [27]. It is considered to be a possible pathogen, since it may deleteriously affect both human and animal health by causing severe necrotic lesions, abscesses, food poisoning, and bacteremia [28].

In this study, 680 milk samples from 170 cows were analyzed (Table-2). CMT was initially performed on all milk samples, and the overall cowlevel prevalence of mastitis was $39.4 \%$ (67/170). The overall occurrence in quarter of the udder was $23.1 \%$ (157/680), with 48 quarters having clinical mastitis and 109 having subclinical mastitis.

The results presented in Table- 3 show that out of 48 samples of mastitic milk studied, $16(33.3 \%)$ were positive for $S$. aureus, whereas 109 samples with subclinical mastitis had only $18(16.5 \%)$ positive for $S$. aureus, producing an overall incidence of $21.6 \%$. Our results are very similar to those of Kirkan et al. [29] who confirmed that $S$. aureus was the major pathogen causing bovine mastitis, being identified from $23.1 \%$ of the inspected farms, and from $28.3 \%$ of the milk samples studied in Turkey. Zeinhom et al. and Mansour et al. $[30,31]$ reported that $12 \%$ and $16.3 \%$ of tested milk samples were $S$. aureus positive, respectively. Jahan et al. [32] reported that the prevalence of
S. aureus was $25.53 \%$, and Pexara et al. [33] reported that the overall occurrence of $S$. aureus in milk was $24.3 \%$, and Ameen et al. [34] found a prevalence of $30 \%$. Many studies have detected a higher occurrence of $S$. aureus such as $62.0 \%$ [35], 36.3\% [36], and $37.32 \%$ [37]. The variation in frequencies of $S$. aureus in milk may be because of improper or suboptimal hygiene or poor farm management [38].

Of 86 human samples, 33 (38.37\%) (44.2\% of hand swabs and $32.6 \%$ of nasal swabs) were $S$. aureus positive (Table-4). This result agreed with those of Khalifa et al. [39] who found a prevalence of S. aureus of $43.33 \%$ from milkers' hands and $36.66 \%$ from their

Table-1: Primer sequences, anticipated product size, and sets of multiplex PCR used.

\begin{tabular}{|c|c|c|c|}
\hline Gene & Primer sequence & $\begin{array}{l}\text { Size } \\
\text { (bp) }\end{array}$ & Reference \\
\hline nuc & $\begin{array}{l}\text { GCGATTGATGGTGATACGGTT } \\
\text { AGCCAAGCCTTGACGAACTAAAGC }\end{array}$ & 279 & {$[35]$} \\
\hline sea & $\begin{array}{l}\text { GGTTATCAATGTGCGGGTGG } \\
\text { CGGCACTITITCTCTTCGG }\end{array}$ & 102 & \\
\hline seb & $\begin{array}{l}\text { GTATGGTGGTGTAACTGAGC } \\
\text { CCAAATAGTGACGAGTTAGG }\end{array}$ & 164 & \\
\hline sec & $\begin{array}{l}\text { AGATGAAGTAGTTGATGTGTATGG } \\
\text { CACACTITAGAATCAACCG }\end{array}$ & 491 & \\
\hline sed & $\begin{array}{l}\text { CCAATAATAGGAGAAAATAAAAG } \\
\text { ATTGGTATITITTCGTTC }\end{array}$ & 495 & \\
\hline see & $\begin{array}{l}\text { AGGTITITCACAGGTCATCC } \\
\text { CTITITTCTTCGGTCAATC }\end{array}$ & 430 & \\
\hline
\end{tabular}

Table-2: Detection of mastitis in cows and quarters using CMT.

\begin{tabular}{lcclcc}
\hline $\begin{array}{l}\text { Type of } \\
\text { sample }\end{array}$ & \multicolumn{2}{c}{ Cow $(\mathbf{n = 1 7 0 )}$} & & \multicolumn{2}{c}{$\begin{array}{c}\text { Quarters }(\mathbf{n = 6 8 0}) \\
\text { that is }(\mathbf{1 7 0 * 4 )}\end{array}$} \\
\cline { 2 - 3 } \cline { 5 - 6 } & No. & \% & & No. & \% \\
\hline $\begin{array}{l}\text { Occurrence } \\
\text { of mastitis }\end{array}$ & 67 & 39.4 & & 157 & 23.1 \\
\hline
\end{tabular}

$\mathrm{CMT}=$ California mastitis test

Table-3: Prevalence of Staphylococcus aureus from clinical and subclinical mastitic milk samples according to ordinary culturing methods

\begin{tabular}{lcc}
\hline Type of milk (mastitis) & \multicolumn{2}{c}{$\begin{array}{c}\text { Frequency of } \\
\text { Staphylococcus aureus }\end{array}$} \\
\cline { 2 - 3 } & No. & \% \\
\hline Clinical mastiti $(n=48)$ & 16 & 33.3 \\
Subclinical mastitis $(n=109)$ & 18 & 16.5 \\
Total $(n=157)$ & 34 & 21.6 \\
\hline
\end{tabular}

Table-4: Prevalence of Staphylococcus aureus from contact human samples according to ordinary culturing methods.

\begin{tabular}{lcc}
\hline Type of sample & \multicolumn{2}{c}{ Frequency of } \\
& \multicolumn{2}{c}{ Staphylococcus aureus } \\
\cline { 2 - 3 } & No. & $\%$ \\
\hline Hand swab $(n=43)$ & 19 & 44.2 \\
Nasal swab $(n=43)$ & 14 & 32.6 \\
Total $(n=86)$ & 33 & 38.37 \\
\hline
\end{tabular}


noses. El-Shenawy et al. [40] recovered S. aureus from $45 \%$ of Egyptian dairy workers. The nasal prevalence $S$. aureus was $33 \%$ [41]. The results of this experiment are quite different from those reported by Rasha [42] who confirmed that the isolation rate from hand swabs was $60 \%$. S. aureus exists in the environment, and humans can transfer it to food, serving as a source of contamination [12].

PCR assay is a rapid and extremely sensitive procedure, and is a very useful tool for the recognition of $S E$ genes in clinical $S$. aureus isolates $[43,44]$. Multiplex PCR using $n u c$ and $S E$-encoding genes was performed after culture (Table-5 and Figure-1) and found that $88.2 \%(30 / 34)$ of milk samples and $93.9 \%$ $(31 / 33)$ of human samples contained $S$. aureus. Our results are compatible with those of Javid et al. and Elbehiry et al. $[19,45]$. Those authors discussed the role of the nuc gene as a potential gold standard marker gene in the detection of $S$. aureus. Another study was conducted in Egypt and confirmed the existence of the $n u c$ gene in all $S$. aureus strains $[45,46]$. This contrasts with the results published by Abdeen et al. [47] who found that approximately $70 \%$ of $S$. aureus isolates carried the nuc gene.

The noses and hands of food handlers carry enterotoxigenic $S$. aureus and so are considered the chief cause of food contamination. The classical $S E$ gene is distributed differently in different countries, due to differences in the habits of food consumption in each region. The PCR products of the recovered $S$. aureus confirmed a relationship between food contaminated with $S$. aureus and the handlers of food [39].

Table-6 shows the enterotoxin profile genes found in $S$. aureus isolates from bovine mastitis, in which sea was the most common enterotoxin, which agreed with previous findings [7,48-50].

The results presented in Table-7 show that sea was the most widespread $S E$ gene in the skin [40] and noses of Egyptian food handlers El-Shenawy et al. [51], either from carriers or patients [43]. Wongboot et al. [43] suggested that the differences in the geographic distribution of $S$. aureus SES genes may be explained if $S E S$ are located on mobile genetic elements that may be exchanged between bacteria of the same or different species.

$S e c$ is the most widespread $S E$ in Italian dairy products [52], while sed is the most predominant $S E$ in dairy products [53]. Udo [54] reported that seb is the most detected $S E$ on the hands of food handlers. Soriano et al. [55] reported that seb and sed were the predominant $S E S$ in food handlers, while Collery et al. [56] reported that seb is the $S E$ most shared among nasal isolates. Chang et al. and Gholamzad et al. [57,58] disagreed with our findings in that they reported that $s e b$ was the most common $S$. aureus enterotoxin gene.

The determination of combined SEs, such as sea-seb and seb-sed in both milk and human isolates, indicates the zoonotic importance of such toxins. This finding agrees with that of Hoque et al. [35] who detected sea+seb. Khalifa et al. [39] and Hasan and Hoshyar [50] reported a combined sea + sec SE.

Globally, the misuse and unsupervised use of antimicrobial agents in the treatment of animal and human infections has contributed to the emergence of antimicrobial resistance [20,37].

Our results concerning the sensitivity of $S$. aureus to different antibiotics show multiple drug resistance, providing further evidence of a potential public and veterinary health hazard (Table-8). Animals can also transmit resistant strains to humans $[4,59,60]$.

We found high levels of resistance to gentamycin and ciprofloxacin in milk and human isolates (Table-9), which agreed with the findings of Hoque et al., Zeinhom et al., Ameen et al., Reta et al. and Klimešová et al. [30,35,61,62]. These authors also detected high resistance to gentamycin in animal

Table-5: Identification of Staphylococcus aureus from milk and human using PCR in comparison with culture methods.

\begin{tabular}{|c|c|c|c|c|c|c|}
\hline \multirow[t]{2}{*}{ Source } & \multicolumn{3}{|c|}{ Culture method } & \multicolumn{3}{|c|}{ PCR } \\
\hline & No. of samples examined & No. of positive & $\%$ & No. of samples examined & No. of positive & $\%$ \\
\hline Milk & 157 & 34 & 21.7 & 34 & 30 & 88.2 \\
\hline Human & 86 & 33 & 38.37 & 33 & 31 & 93.9 \\
\hline
\end{tabular}

$\mathrm{PCR}=$ Polymerase chain reaction

Table-6: Enterotoxin profile genes found in Staphylococcus aureus isolates from bovine mastitis.

\begin{tabular}{lccc}
\hline Enterotoxin gene & \multicolumn{3}{c}{ Number (\%) of Staphylococcus aureus isolates } \\
\cline { 2 - 4 } & Clinical mastitis milk (n=13) & Subclinical mastitis milk (n=21) & Total (n=34) \\
\hline Sea & 3 & 7 & 10 \\
Seb & 0 & 3 & 3 \\
Sec & 1 & 2 & 3 \\
Sed & 1 & 1 & 2 \\
See & 0 & 2 & 2 \\
Sea-seb & 0 & 1 & 1 \\
Seb-sed & 1 & 0 & 1 \\
Total & $6(46.2)$ & $16(76.2)$ & $22(64.7)$ \\
\hline
\end{tabular}


Available at www.onehealthjournal.org/Vol.7/No.1/9.pdf

Table-7: Enterotoxin profile genes found in Staphylococcus aureus isolates from human.

\begin{tabular}{lccc}
\hline Enterotoxin gene & \multicolumn{2}{c}{ Number (\%) of Staphylococcus aureus isolates } \\
\cline { 2 - 4 } & Hand swab $(\mathbf{n = 1 9 )}$ & Nasal swab $(\mathbf{n = 1 4 )}$ & Total $(\mathbf{n = 3 3 )}$ \\
\hline Sea & 5 & 3 & 8 \\
Seb & 2 & 1 & 3 \\
Sec & 1 & 2 & 3 \\
Sed & 0 & 1 & 1 \\
See & 1 & 1 & 1 \\
Sea-seb & 2 & 1 & 3 \\
Seb-sed & 1 & $9(64.3)$ & 2 \\
Total & $12(63.2)$ & & $21(63.6)$ \\
\hline
\end{tabular}

Table-8: Multidrug resistance (MDR) observed among Staphylococcus aureus isolates from milk and human samples.

\begin{tabular}{lccccc}
\hline Sample type & \multicolumn{5}{c}{ Number of antimicrobials } \\
\cline { 2 - 6 } & $\mathbf{1}$ & $\mathbf{2}$ & $\mathbf{3}$ & $\mathbf{4}$ & $\mathbf{5}$ \\
\cline { 2 - 6 } & & \multicolumn{5}{c}{ No. (\%) of MDROs } \\
\hline Milk samples $n=34$ & $0(0.0)$ & $10(23.5)$ & $15(32.4)$ & $5(14.7)$ & $4(11.8)$ \\
Human samples $n=33$ & $4(12.1)$ & $9(27.3)$ & $6(18.2)$ & $14(42.4)$ & $0(0.0)$ \\
Total $(n=67)$ & $4(5.97)$ & $19(28.36)$ & $21(31.34)$ & $19(28.36)$ & $4(5.97)$ \\
\hline
\end{tabular}

Table-9: Resistance of Staphylococcus aureus isolates from milk and human to different antibacterial agents.

\begin{tabular}{|c|c|c|c|c|c|c|}
\hline \multicolumn{3}{|c|}{ Antimicrobial Disk concentration Zone of resistance } & \multicolumn{2}{|c|}{ Milk isolates n (34) } & \multicolumn{2}{|c|}{ Human isolates $\mathbf{n}(33)$} \\
\hline & & & \multirow{2}{*}{$\frac{\text { No. }}{13}$} & \multirow{2}{*}{$\begin{array}{l}\% \\
38\end{array}$} & \multirow{2}{*}{$\frac{\text { No. }}{12}$} & \multirow{2}{*}{$\begin{array}{c}\% \\
36.4\end{array}$} \\
\hline Penicillin & 10 units & $\leq 28$ & & & & \\
\hline Gentamicin & $10 \mu \mathrm{g}$ & $\leq 12$ & 6 & 17.6 & 8 & 24.2 \\
\hline Azithromycin & $15 \mu \mathrm{g}$ & $\leq 13$ & 0 & 0 & 1 & 3 \\
\hline Ciprofloxacin & $5 \mu \mathrm{g}$ & $\leq 15$ & 9 & 26.5 & 10 & 30.3 \\
\hline Levofloxacin & $5 \mu \mathrm{g}$ & $\leq 15$ & 3 & 8.8 & 2 & 6 \\
\hline Clindamycin & $2 \mu \mathrm{g}$ & $\leq 14$ & 0 & 0 & 0 & 0 \\
\hline Erythromycin & $15 \mu \mathrm{g}$ & $\leq 13$ & 4 & 11.8 & 6 & 18.2 \\
\hline Doxycycline & $30 \mu \mathrm{g}$ & $\leq 12$ & 5 & 14.7 & 4 & 12.1 \\
\hline Norfloxacin & $10 \mu \mathrm{g}$ & $\leq 12$ & 1 & 2.9 & 0 & 0 \\
\hline
\end{tabular}

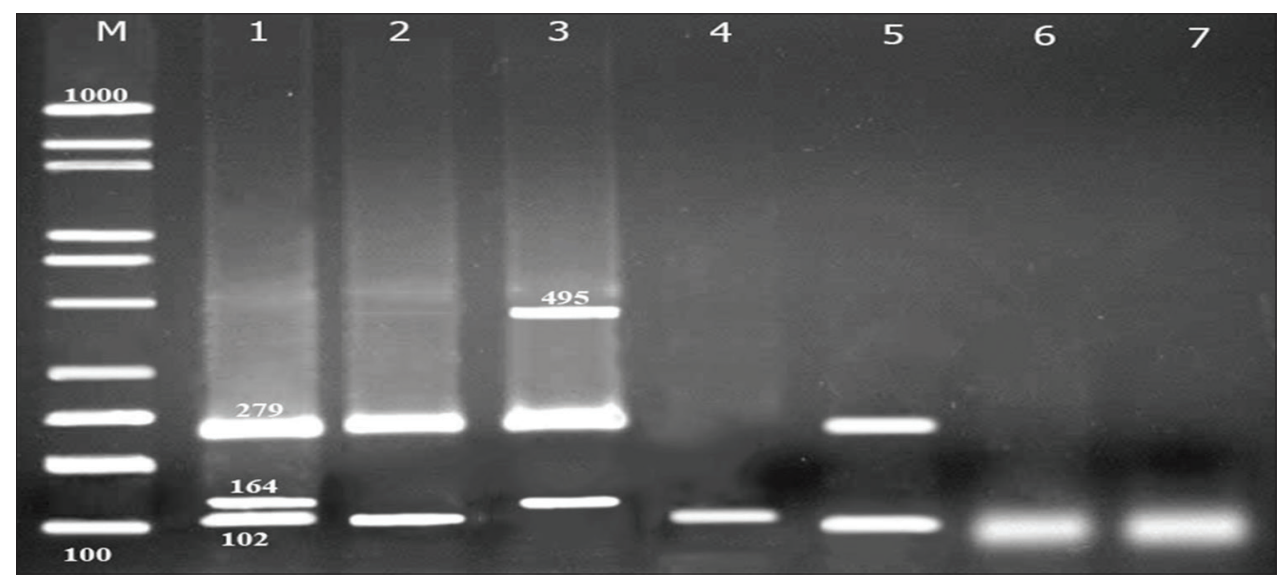

Figure-1: Gel electrophoresis of multiplex polymerase chain reaction to nuc gene and five Staphylococcus aureus enterotoxin genes (sea, seb, sec, sed, and see).

isolates and to gentamycin and ciprofloxacin in human isolates. Higher sensitivity was recorded to gentamicin in human isolates in Iran [44], while, El Faramaway et al. [63] in Egypt found increased resistance in $S$. aureus isolates from clinical mastitis to penicillin and gentamicin. Pexara et al. [33] indicated that a high percentage of resistance to clindamycin was detected among $S$. aureus isolates.

\section{Conclusion}

The data presented here show that pathogenic $S$. aureus was isolated from milk and human samples at various numbers, probably because of poor hygiene. Multiplex PCR targeting the $n u c$ gene and SEs can lead to rapid and accurate detection of $S$. aureus in milk. $S$. aureus carries multiple virulence genes which are of clinical importance in $S$. aureus. A high prevalence 
of multiple drug-resistant $S$. aureus isolates provides further evidence for potential public and veterinary health hazards.

\section{Authors' Contributions}

MSD and SAZ: Conceptualization. NAI, MAS, SAZ and EMAT: Methodology. MSD, YFE, NAI, SAZ, and MAS: Validation. SAZ, NAI, and GAP: Formal analysis. MSD, NAI, YFE, SAZ, and MAS: Investigation. YFE, SAZ, and MAS: Resources. MSD, SAZ, and NAI: Data curation. NAI, YFE, and MAS: Writing - original draft preparation. MSD, SAZ, and NAI: Writing - review and editing. MSD and YFE: Visualization. SAZ, MAS, and YFE: Supervision. SAZ, MAS, and YFE: Project administration. All authors read and approved the final manuscript.

\section{Acknowledgments}

The authors would like to thank staff members of Bacteriology Unit, Animal Health Research Institute, Dokki, Egypt, for their support to conduct the study. The authors did not receive any funds for this study.

\section{Competing Interests} interests.

The authors declare that they have no competing

\section{Publisher's Note}

Veterinary World (Publisher of International Journal of One Health) remains neutral with regard to jurisdictional claims in published institutional affiliation.

\section{References}

1. Le Marechal, C., Seyffert, N., Jardin, J., Hernandez, D., Jan, G., Rault, L., Azevedo, V., François, P., Schrenzel, J., van de Guchte, M., Even, S., Berkova, N., Thiéry, R., Fitzgerald, J.R., Vautor, E. and Le Loir, Y. (2011) Molecular basis of virulence in Staphylococcus aureus mastitis. PLoS One, 6(11): e27354.

2. Srednik, M.E., Usongo, V., Lepine, S., Janvier, X., Archambault, M.A. and Gentilini, E.R. (2018) Characterisation of Staphylococcus aureus strains isolated from mastitis bovine milk in Argentina. J. Dairy Res., 85(1): 57-63.

3. Boss, R., Cosandey, A., Luini, M., Artursson, K., Bardiau, M., Breitenwieser, F., Hehenberger, E., Lam, T., Mansfeld, M., Michel, A., Mösslacher, G., Naskova, J., Nelson, S., Podpečan, O., Raemy, A., Ryan, E., Salat, O., Zangerl, P., Steiner, A. and Graber, H.U. (2016) Bovine Staphylococcus aureus: Subtyping, evolution, and zoonotic transfer. J. Dairy Sci., 99(1): 515-528.

4. Guimaraes, F.F., Manzi, M.P., Joaquim, S.F., RichiniPereira, V.B. and Langoni, H. (2017) Short communication: Outbreak of methicillin-resistant Staphylococcus aureus (MRSA)-associated mastitis in a closed dairy herd. J. Dairy Sci., 100(1): 726-730.

5. Silva, N.C.C., Guimarães, F.F., Manzi, M.P., Júnior, E.A.F., Gómez-Sanz, P.G., Langoni, H., Rall, V.L.M. and Torres, C. (2014) Methicillin-resistant Staphylococcus aureus of lineage ST398 as cause of mastitis in cows. Lett. Appl. Microbiol., 59(6): 665-669.

6. Akineden, O., Hassan, A.A., Schneider, E. and Usleber, E. (2008) Enterotoxigenic properties of Staphylococcus aureus isolated from goat's milk cheese. J. Food Microbiol., 124(2): 211-216.

7. Argudin, M.A., Mendoza, M.C. and Rodicio, M.R. (2010)
Food poisoning and Staphylococcus aureus enterotoxins. Toxins (Basel), 2(7): 1751-1773.

8. Tallent, S.M., Bennett, R.W.A. and Hait, J.M. (2017) Staphylococcal enterotoxins detection methods. In: Bacteriological Analytical Manual BAM. Food and Drug Administration, United States.

9. Sharma, N.K., Rees, C.E.D. and Dodd, C.E. (2002) Development of a single-reaction multiplex PCR toxin typing assay for Staphylococcus aureus strains. Appl. Environ. Microbiol., 66(4): 1347-1353.

10. Gandra, E.A.F., Silva, M.A. and J.A. da Silva, W.P. (2016) Detection by multiplex PCR of Staphylococcus aureus, $S$. intermedius and $S$. hyicus in artificially contaminated milk. Ciênc. Rural, 46(8): 1418-1423.

11. Scott, E. (2003) Food safety and foodborne diseases in $21^{\text {st }}$ century homes. Can. J. Infect. Dis., 14(5): 277-280.

12. Fisher, E.L., Otto, M. and Cheung, G.Y.C. (2018) Basis of virulence in enterotoxin-mediated staphylococcal food poisoning. Front. Microbiol., 9: 436.

13. Acosta, A.C., Oliveira, P.R.F., Albuquerque, L., Silva, I.F., Medeiros, E.S., Costa, M.M., Pinheiro, J.W. Jr. and Mota, R.A. (2018) Frequency of Staphylococcus aureus virulence genes in milk of cows and goats with mastitis. Pesq. Vet. Bras, 38(11): 2029-2036.

14. Garciaa, S.N.O., Osburn, B.I. and Cullor, J.S. (2019) A one health perspective on dairy production and dairy food safety. One Health, 7: 100086.

15. Ercoli, L., Gallina, S., Nia, Y., Auvray, F., Primavilla, S., Guidi, F., Pierucci, B., Graziotti, C., Decastelli, L. and Scuota, S. (2017) Investigation of a staphylococcal food poisoning outbreak from a chantilly cream Dessert, in Umbria (Italy). Foodborne Pathog. Dis., 14(7): 407-413.

16. Daum, R.S. (2018) Staphylococcus aureus. In: Long, S.S., Prober, C.G. and Fischer, M., editors. Principles and Practice of Pediatric Infectious Diseases. $5^{\text {th }}$ ed. Elsevier, Amsterdam, Netherlands. p692-706.e694.

17. Bharathy, S., Gunaseelan, L., Porteen, K. and Bojiraj, M. (2015) prevalence of Staphylcoccus aureus in raw milk: Can it be a potential public health threat? Int. J. Adv. Res., 3(2): 801-806.

18. Kuzma, K., Malinowski, E., Lassa, H. and Klossowska, A. (2003) Specific detection of Staphylococcus aureus by PCR in intramammary infection. Bull. Vet. Inst. Pulawy, 47(1): 183-190.

19. Javid, F., Taku, A., Bhat, M.A., Badroo, G.A., Mudasir, M. and Sofi, T.A. (2018) Molecular typing of Staphylococcus aureus based on coagulase gene. Vet. World, 11(4): 423.

20. Sharma, V., Sharma, S., Dahiya, D.K., Khan, A., Mathur, M. and Sharma, A. (2017) Coagulase gene polymorphism, enterotoxigenicity, biofilm production, and antibiotic resistance in Staphylococcus aureus isolated from bovine raw milk in North West India. Ann. Clin. Microbiol. Antimicrob., 16(1): 65 .

21. Diab, M.S. Zaki., R.S. Ibrahim, N.A. and Abd El Hafez, M.S. (2019) Prevalence of multidrug resistance non-typhoidal salmonellae isolated from layer farms and humans in Egypt. World Vet. J., 9(4): 280-288.

22. Hoque, M.N., Das, Z.C., Talukder, A.K., Alam, M.S. and Rahman, A.N. (2015) Different screening tests and milk somatic cell count for the prevalence of subclinical bovine mastitis in Bangladesh. Trop. Anim. Health Prod., 47(1): 79-86.

23. Forbes, B.A., Sahm, D.F. and Weissfeld, A.S. (2007) Baily and Scott's Diagnostic Microbiology. $2^{\text {th }}$ ed. Mosby, Elsevier, St. Louis, Missouri.

24. Aldous, W.K., Pounder, J.I., Cloud, J.L. and Woods, G.L. (2005) Comparison of six methods of extracting Mycobacterium tuberculosis DNA from processed sputum for testing by quantitative real-time PCR. J. Clin. Microb., 43(5): 2471-2473.

25. Oikonomou, G., Bicalho, M.L., Meira, E., Rossi, R.E., Foditsch, C., Machado, V.S., Teixeira, A.G.V., 
Santisteban, C., Schukken, Y.H. and Bicalho, R.C. (2014) Microbiota of cow's milk; distinguishing healthy, sub-clinically and clinically diseased quarters. PLoS One, 9(1): e85904.

26. Clinical and Laboratory Standards Institute. (2015) Performance Standards for Antimicrobial Susceptibility Testing; Twenty-Fifth Informational Supplement, CLSI Document M100-S25. Clinical and Laboratory Standards Institute, Wayne, PA.

27. Hanson, B.M., Dressler, A.E., Harper, A.L., Scheibel, R.P., Wardyn, S.E., Roberts, L.K., Kroeger, J.S. and Smith, T.C. (2011) Prevalence of Staphylococcus aureus and methicillin-resistant Staphylococcus aureus (MRSA) on retail meat in Iowa. J. Infect. Public Health, 4(4): 169-174.

28. Reacher, M.H., Shah, A., Livermore, D.M., Wale, M.C., Graham, C., Johnson, A.P., Heine, H., Monnickendam, M.A., Barker, K.F., James, D. and George, R.C. (2000) Bacteraemia and antibiotic resistance of its pathogens reported in England and Wales between 1990 and 1998: Trend analysis. Br. Med. J., 320(7229): 213-216.

29. Kirkan, S., Goksoy, E.O. and Kaya, O. (2005) Identification and antimicrobial susceptibility of Staphylococcus aureus and coagulase-negative staphylococci from bovine mastitis in the Aydin region of Turkey. Turk. J. Vet. Anim. Sci., 29(3): 791-796.

30. Zeinhom, M.M.A., Abdel-Latef, G.K. and Jordan, K. (2015) The use of multiplex PCR to determine the prevalence of enterotoxigenic Staphylococcus aureus isolated from Raw Milk, Feta Cheese, and Hand Swabs. J. Food Sci., 80(12): 2932-2936.

31. Mansour, A.S., Wagih, G.E. Morgan, S.D., Elhariri, M., El-shabrawy, M.A., Abuelnaga, A.S.M. and Elgabry, E.A. (2017) Detection of Staphylococcus aureus enterotoxigenic strains in bovine raw milk by reversed passive latex agglutination and multiplex polymerase chain reaction. Vet. World, 10(8): 843-847.

32. Jahan, M.R., Parvej, M.S., Chawdhury, S.M.Z., Haque, M.E., Talukder, M.A.K. and Ahmed, S. (2015) Isolation and characterization of Staphylococcus aureus from raw cow milk in Bangladesh. J. Adv. Vet. Anim. Res., 2(1): 49-55.

33. Pexara, A.S., Solomakos, N., Sergelidis, D., Angelidis, A.S. and Govaris, A. (2016) Occurrence and antibiotic resistance of enterotoxigenic Staphylococcus aureus in raw ovine and caprine milk in Greece. Dairy Sci. Technol., 96: 345-357.

34. Ameen, F., Reda, S.A., El-Shatoury, S.A., Riad, E.M., Enany, M.E. and Alarfaj, A.A. (2019) Prevalence of antibiotic-resistant mastitis pathogens in dairy cows in Egypt and potential biological control agents produced from plant endophytic actinobacteria. Saudi J. Biol. Sci., 26(7): 1492-1498.

35. Hoque, M.N., Das, Z.C., Rahman, A., Haider, M.G. and Islam, M.A. (2018) Molecular characterization of Staphylococcus aureus strains in bovine mastitis milk in Bangladesh. Int. J. Vet. Sci. Med., 6(1): 53-60.

36. Algammal, A.M., Enany, M.E., El-Tarabili, R.M., Ghobashy, M.O. and Helmy, Y.A. (2020) Prevalence, antimicrobial resistance profiles, virulence and enterotoxin-determinant genes of MRSA isolated from subclinical bovine mastitis samples in Egypt. Pathogens, 9(5): 362.

37. Keyvan, E., Yurdakul, O., Demirtas, A., Yalcin, H. and Bilgen, N. (2020) Identification of methicillin-resistant Staphylococcus aureus in bulk tank milk. Food Sci. Technol., 40(1): 150-156.

38. Ateba, C.N., Mbewe, M., Moneoang, M.S. and Bezuidenhout, C.C. (2010) Antibiotic-resistant Staphylococcus aureus isolated from milk in the Mafikeng area, North West province, South Africa. S. Afr. J. Sci., 106(1-6): 243.

39. Khalifa, N.O., Elhofy, F.I., Fahmy, H.A. and Barakat, A.M.A. (2015) Epidemiological and genetic studies of enterotoxigenic Staphylococcus aureus isolated from goat and human.
Am. J. Infect. Dis. Microbiol., 3(1): 32-37.

40. El-Shenawy, M., Tawfeek, M., El-Hosseiny, L., El-Shenawy, M., Farag, N., Baghdadi, H., Saleh, O., Mañes, J. and Soriano, J.M. (2014) Cross-sectional study of skin carriage and enterotoxigenicity of Staphylococcus aureus among food handlers. Open J. Med. Microbiol., 4(1): 16-22.

41. Appiah, V.A., Pesewu, G.A., Kotey, F.C., Boakye, A.N., Duodu, S., Tette, E.M.A., Nyarko, M.Y. and Donkor, E.S. (2020) Staphylococcus aureus nasal colonization among children with sickle cell disease at the children's hospital, Accra: Prevalence, risk factors, and antibiotic resistance. Pathogens, 9(5): 329.

42. Rasha, M.A.G. (2008) Studies on Some Zoonotic Bacterial Food Borne Infection. Master, Faculty of Veterinary Medicine. Zagazig University, Egypt.

43. Wongboot, W., Chomvarin, C., Engchanil, C. and Chaimanee, P. (2013) Multiplex PCR for detection of superantigenic toxin genes in methicillin-sensitive and methicillin-resistant Staphylococcus aureus isolated from patients and carriers of a hospital in northeast Thailand. Southeast Asian J. Trop. Med. Public Health, 44(4): 660-671.

44. Yaslianifard, S.J., Mirzaii, M.S.M., Kermanian, F.F., Marashi, S.M.A., Dehaghi, N.K., Alimorad, S. and Yaslianifard, S. (2017) Virulence genes in Staphylococcus aureus strains isolated from different clinical specimens in an Iranian hospital. EC Microbiol., 5(3): 86-92.

45. Elbehiry, A., Al-Dubaib, M., Marzouk, E. and Moussa, I. (2019) Antibacterial effects and resistance induction of silver and gold nanoparticles against Staphylococcus aureus-induced mastitis and the potential toxicity in rats. Microbiologyopen, 8(4): e00698.

46. Abd El-Hamid, M. and Bendary, M.M. (2013) Association between agr alleles and toxin gene profiles of $S$. aureus isolates from human and animal sources in Egypt. Int. J. Adv. Res., 1(8): 133-144.

47. Abdeen, E.E., Mousa, W.S., Salam, S.Y.A., Al-Maary, K.S., Mubarak, A.S., Moussa, I.M., Hemeg, H.A., Almuzaini, A.M., Alajaji, A.I., Alsubki, R.A. and Elbehiry, A. (2020) Antibiogram and phylogenetic diversity of enterotoxigenic Staphylococcus aureus strains from milk products and public health implications. Saudi J. Biol. Sci., 27(8): 1968-1974.

48. Ciftci, A., Onuk, E.E., Fındık, A., Yıldırım, T. and Sogut, M.U. (2009) Molecular typing of Staphylococcus aureus strains from bovine mastitis by pulsed-field gel electrophoresis and polymerase chain reaction based on coagulase and protein A gene polymorphisms. J. Vet. Diagn. Invest., 21(6): 849-853.

49. Pinchuk, I.V., Beswick, E.J. and Reyes, V.E. (2010) Staphylococcal enterotoxins. Toxins, 2(8): 2177-2197.

50. Hasan, N.S. and Hoshyar, D.F. (2019) Detection of enterotoxigenic Staphylococcus aureus strains in raw milk of cows reared in Erbil Province/Iraq. Zanco J. Pure Appl. Sci., 31(4): 50-60.

51. El-Shenawy, M., El-Hosseiny L., Tawfeek, M., El-Shenawy, M., Baghdadi, H., Saleh, O., Mañes, J. and Soriano, J.M. (2013) Nasal carriage of enterotoxigenic Staphylococcus aureus and risk factors among food handlers-Egypt. Food Public Health, 3(6): 284-288.

52. Morandi, S., Brasca, M., Andrighetto, C., Lombardi, A. and Lodi, R. (2009) Phenotypic and genotypic characterization of Staphylococcus aureus strains from Italian dairy products. Int. J. Microbiol., 2009: 501362.

53. Normanno, G., La Salandra, G., Dambrosio, A., Quaglia, N.C., Corrente, M., Parisi, A., Santagada, G., Firinu, A., Crisetti, E. and Celano, G.V. (2007) Occurrence, characterization and antimicrobial resistance of enterotoxigenic Staphylococcus aureus isolated from meat and dairy products. Int. J. Food Microbiol., 115(3): 290-296.

54. Udo, E.E., Al-Bustan, M.A., Jacob, L.E. and Chugh, T.D. (1999) Enterotoxin production by coagulase-negative 
staphylococci in restaurant workers from Kuwait City may be a potential cause of food poisoning. J. Med. Microbiol., 48(9): 819-823.

55. Soriano, J.M., Font, G., Molto, J.C. and Males, J. (2002) Enterotoxigenic staphylococci and their toxins in restaurant foods. Trends Food Sci. Technol., 13(2): 60-67.

56. Collery, M.M., Smyth, D.S., Twohig, J.M., Shore, A.C., Coleman, D.C. and Smyth, C.J. (2008) Molecular typing of nasal carriage isolates of Staphylococcus aureus from an Irish university student population based on toxin gene PCR, agr locus types and multiple locus, variable number tandem repeat analysis. J. Med. Microbiol., 57(Pt 3): 348-358

57. Chang, Y., Gao, H., Zhu, Z., Ye, S., Yang, Y. and Shen, X. (2016) High prevalence and properties of enterotoxin-producing Staphylococcus aureus ST5 strains of good sources in China. Foodborne Pathog. Dis., 13(7): 386-390.

58. Gholamzad, M., Khatami, M.R., Ghassemi, S., Vaise Malekshahi, Z. and Shooshtari, M.B. (2015) Detection of Staphylococcus enterotoxin B (SEB) using an immune chromatographic test strip. Jundishapur J. Microbiol, 8(9): e26793.

59. Shah, M.S., Qureshi, S., Kashoo, Z., Farooq, S., Wani, S.A.,
Hussain, M.I., Banday, M.S., Khan, A.A., Gull, B., Habib, A., Khan, S.M. and Dar, B.A. (2019) Methicillin resistance genes and in vitro biofilm formation among Staphylococcus aureus isolates from bovine mastitis in India. Comp. Immunol. Microbiol. Infect. Dis., 64: 117-124.

60. Yehia, H.M., Al-Masoud, A.H., Alarjani, K.M. and Alamri, M.S. (2020) Prevalence of methicillin-resistant (mecA gene) and heat-resistant Staphylococcus aureus strains in pasteurized camel milk. J. Dairy Sci., 103(7): 5947-5963.

61. Reta, M.A., Bereda, T.W. and Alemu, A.N. (2016) Bacterial contaminations of raw cow's milk consumed at Jigjiga City of Somali Regional State, Eastern Ethiopia. Int. J. Food Contam., 3(1): 4.

62. Klimešová, M., Manga, I., Nejeschlebová, L., Horáček, J., Ponížil, A. and Vondrušková, E. (2017) Occurrence of Staphylococcus aureus in cattle, sheep, goat, and pig rearing in the Czech Republic. Acta Vet. Brno, 86(1): 3-10.

63. El Faramaway, R.T., Abdeen, E.E., Ashraf, A.A. and Mousa, W.S. (2019) Antibiogram profile and molecular characterization of Coa and spa genes of methicillin-resistant Staphylococcus aureus (MRSA) from clinical mastitis. Alex. J. Vet. Sci., 61(1): 32-38. 